\title{
Meer dan een zwarte bladzijde
}

\author{
Richard Kofi \& Annemarie de Wildt ${ }^{*}$
}

Bij lezingen, debatten en evenementen over het beladen erfgoed van het Nederlandse slavernijverleden komen ze elkaar telkens tegen: Richard Kofi en Annemarie de Wildt. Kofi is kunstenaar en tentoonstellingsmaker bij het Tropenmuseum, waar hij onder andere de tentoonstelling Het heden van het slavernijverleden maakte. De Wildt is historica en sinds 1995 conservator bij het Amsterdam Museum, waar ze tientallen tentoonstellingen maakte rond het dagelijks leven, maar ook over beladen onderwerpen als prostitutie, voetbalfans en de relatie tussen Amsterdam en de Oranjes. In hun werk onderzoeken Kofi en De Wildt de consequenties van wereldwijde geopolitieke kwesties op lokale niveaus en vice versa. Ze proberen het narratief van hun musea te dekoloniseren en de hegemoniale canonieke westerse grenzen te doorbreken. Ze zijn op zoek naar nieuwe verhalen en andere stemmen die inspireren om de wereld anders te bekijken en, liever nog, te veranderen (Jouwe, 2018, p. 131). In dit artikel bespreken ze de samenwerkingen die het mogelijk hebben gemaakt om alternatieve geschiedenissen bloot te leggen en doen ze verslag van de dilemma's rondom de erfenis van de Nederlandse slavernij in de twee Amsterdamse musea waarvoor zij werken. Zo gaan ze samen in op de vraag hoe nieuwe inzichten uit de wetenschap het beste een publieke plek en invulling kunnen krijgen.

Het Amsterdam Museum, opgericht in 1926 en sinds 1975 gevestigd in een voormalig weeshuis aan de Kalverstraat, wil de geschiedenis van Amsterdam tot leven brengen. Onderdeel daarvan is het slavernijverleden. Amsterdam was immers van 1683 tot 1795, als een van de oprichters van de Sociëteit van Suriname, medeeigenaar van de kolonie Suriname, samen met de West-Indische Compagnie. Overal ter wereld staan naar Amsterdam genoemde forten, onder andere op Curaçao, in Suriname en Ghana, op Ambon, Sint-Maarten en Manado. En een aanzienlijk deel van de Amsterdamse bevolking heeft roots in het Caraïbisch gebied en de voormalige kolonie Indonesië. Maar toch hadden het slavernijverleden en de gevolgen daarvan lang geen prominente plaats in het museum. Wel werd er in verschillende tentoonstellingen, onder andere Allemaal Amsterdammers (1985) en Suiker (2005), enige aandacht aan besteed. Sinds 2012, in de aanloop naar de herdenking van 150 jaar afschaffing van de slavernij, maar ook dankzij de 'Zwarte Piet is Racisme'-campagne, is de aandacht toegenomen.

Het Tropenmuseum in Amsterdam maakt sinds 2014 samen met Museum Volkenkunde in Leiden, het Afrika Museum in Berg en Dal en het Wereldmuseum in Rotterdam onderdeel uit van het Nationaal Museum van Wereldculturen. De levensloop van het Tropenmuseum begon in 1864, toen de Maatschappij ter Bevordering van Nijverheid Frederik van Eeden opdracht gaf een verzameling aan

* Richard Kofi is kunstenaar en tentoonstellingsmaker bij het Tropenmuseum. Annemarie de Wildt is historica en conservator bij het Amsterdam Museum. 
te leggen voor een toekomstig museum over de Nederlandse overzeese gebiedsdelen. In 1871 opende het museum en was daarmee het eerste Koloniaal Museum ter wereld, gevestigd op de benedenverdieping van Paviljoen Welgelegen in Haarlem. In 1923 verhuisde het naar een groot nieuw gebouw in Amsterdam, waar de organisatie verder ging als Koloniaal Instituut en Koloniaal Museum. Lange tijd fungeerde deze organisatie als wetenschappelijk kenniscentrum, maar ook als etalage van de Nederlandse koloniale ondernemingen en politiek. Pas vanaf 1950 heet het museum Tropenmuseum. Sinds de fusie in 2014 gaat het museum nadrukkelijker de confrontatie aan met het eigen beladen verleden. Nieuw onderzoek legt verbindingen tussen de eigen collectie en hedendaagse menselijke verhalen, met de culturele dynamiek en diversiteit die de wereld rijk is.

\section{Schaduw van het kolonialisme}

De oude traditie van de stedentrots van waaruit stadsmusea als het Amsterdam Museum werden opgericht, is taai. De stadscollectie, zeker wat betreft de oudere objecten, toont vooral waar de rijke burgers van Amsterdam trots op waren. Een mooi voorbeeld is het bekende beeld van de Amsterdamse of Nederlandse maagd tussen personificaties van de werelddelen of koloniën die hun gaven komen aanbieden. Dat staat op schilderijen, op het timpaan op het Paleis op de Dam - het voormalige Amsterdamse stadhuis - en het paneel Hulde der Koloniën op de gouden koets. Regelmatig verdwijnen tegenwoordig standbeelden vanwege hun koloniale verleden. Het beeld van de stedenmaagd moet ook (figuurlijk) gekanteld worden door te laten zien dat het propaganda is. Dit was de manier waarop Amsterdam graag naar zichzelf keek. Kantelen begint met kennen, met goed kijken naar dat iconische beeld. Het werk Colonies (2017) van Iswantho Hartono, een recente aankoop van het Amsterdam Museum, kan ons op een andere manier laten kijken. Hartono maakt letterlijk de schaduw van de koloniale geschiedenis zichtbaar met zijn interpretatie van de voorstudie van het paneel, uitgevoerd in witgeverfd staal, dat een donkere schaduw werpt op de muur erachter. Juist kunstenaars kunnen zichtbaar maken wat er in de koloniale periode, en nog lang daarna, verborgen was. Ken Doorson refereert met zijn fictieve portret van Pauline met manumissiebrief (2016) aan de mensen in het negentiende-eeuwse Paramaribo die zichzelf en anderen vrijkochten, nog voor de afschaffing van de slavernij in 1863.

Bij de presentatie van deze nieuwe aanwinst in februari 2017 hield juriste Ellen Neslo een lezing over haar promotieonderzoek naar de opkomst van een gekleurde elite in koloniaal Suriname in de negentiende eeuw (Neslo \& Aurelia, 2016). Een vol auditorium luisterde naar haar verhaal en bekeek daarna het portret van Doorson. Veel mensen hadden het gevoel dat een van de mensen waarover Ellen vertelde tot leven was gekomen. Ook een kunstenaar als Iris Kensmil liet zich voor haar in 2013 verworven drieluik Out of History inspireren door historische kennis. Zij schilderde fictieve portretten van Elisabeth Samson, een rijke zwarte plantagehoudster, de vrijgekochte Wilhelmina van Kelderman en Fabi Labi Dikan, granman van een groep marrons (slaafgemaakten die gevlucht 
waren van de plantages). Deze mensen uit de achttiende eeuw vielen buiten het schema 'zwarte slaaf en witte meester'. Ze hebben hun leven in eigen hand genomen (Reichwein, 2016).

Het Tropenmuseum heeft al decennialang als doel de erfenissen van ons gedeelde slavernijverleden in de Nederlandse maatschappij zichtbaar en bespreekbaar te maken. De spraakmakende tentoonstelling Wit over Zwart, in 1989 samengesteld door Felix de Rooy, liet zien dat alledaagse erfgoedobjecten zoals stripboeken, speelgoed en reclameaffiches boodschappen en beelden vertonen die gebaseerd zijn op racistische machtsstructuren en de stereotiepe beeldvorming over zwart mensen. Van vergelijkbare impact waren de tentoonstellingen Kunst van overleven (2009) en Zwart \& Wit (2013), mede samengesteld door Alex van Stipriaan. De rapporten, uitkomsten en teksten van deze tentoonstellingen dienden als inspiratiebron voor hedendaagse projecten zoals 'Het heden van het slavernijverleden'. Het tentoonstellingsconcept daarvoor is gemaakt als reactie op de conferentie 'Gedeelde Geschiedenis' die in februari 2017 in het museum plaatsvond. Een dag lang gingen kritische kunstenaars, muzikanten, activisten, academici en museummedewerkers met elkaar in gesprek over de erfenissen van het koloniale en slavernijverleden. Er werd vooral kritisch gesproken over manieren waarop erfgoedinstellingen zich respectvoller tot hun eigen collecties kunnen verhouden. We besloten de tentoonstelling Het heden van het slavernijverleden te maken: een work in progress, ter voorbereiding van een nieuwe vaste opstelling.

Onderdeel uitmaken van musea met rijke tradities brengt verantwoordelijkheden met zich. Onze instituten worden kritisch gevolgd door de kunstwereld, de wetenschap en de maatschappij, omdat onze tentoonstellingen en evenementen over mensen gaan. Dit maakt het van groot belang om op een open en proactieve manier samen te werken en, waar mogelijk, onze eigen zeggenschap binnen de instituten met anderen te delen.

\section{Stemmen van buiten}

Bij het slavernijverleden zijn ook het eigentijdse perspectief op en gedachten over het verleden relevant. Zoals Het heden van het slavernijverleden laat zien, werkt slavernij van toen nog steeds door in de relaties van nu en daar moeten wij ons in de museale praktijk bewust van zijn. De zoektocht naar transparantie, inclusiviteit en diversiteit is al langer gaande binnen het Tropenmuseum. De Decolonize The Museum Conference in 2016 opende de ogen van veel museummedewerkers. Actiegroep \#decolonizethemuseum confronteerde ons met achterhaald, discriminerend of beledigend woordgebruik en bevooroordeelde witte Eurocentrische beeldvorming in de tentoonstellingsteksten van de oude vaste opstelling. Zo werd er in onze teksten te weinig actief taalgebruik toegepast wanneer het ging over geweld en onderdrukking: alsof mensen zomaar tot slaaf gemaakt werden, alsof de schepen niet bestuurd werden en alsof veldslagen in Indonesië uit het niets tot stand kwamen. Sinds die conferentie is er in de organisatie veel veranderd. Om in Het heden van het slavernijverleden de onbedoelde reproductie van koloniale beeldvorming en taalgebruik tegen te gaan zijn we met academici en activisten in 


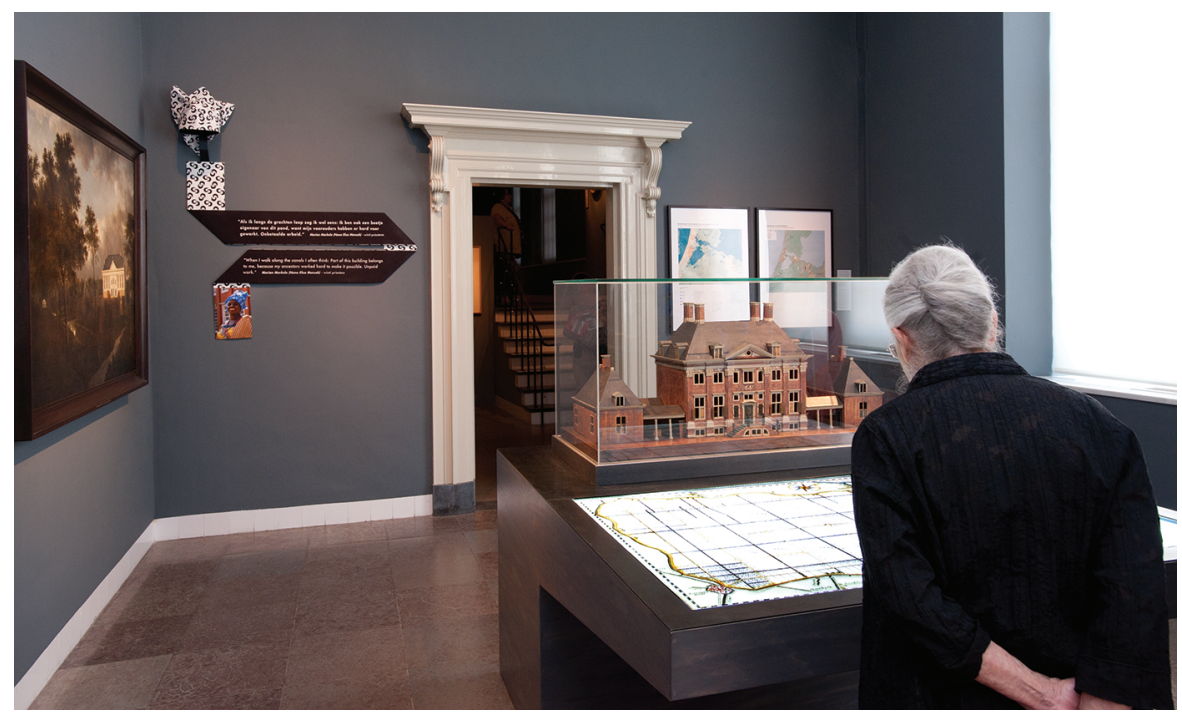

Figuur 1 Citaat van Marian Markelo, ook bekend als Nana Efua, in het slavernijspoor in de tentoonstelling De Gouden Eeuw, 2013. Foto Amsterdam Museum, Monique Vermeulen.

gesprek gegaan en hielpen Simone Zeefuik, Hodan Warsame en Phoenix van \#decolonizethemuseum ons met het redigeren van de tentoonstellingsteksten.

Het Amsterdam Museum geeft sinds de jaren tachtig stemmen van Amsterdammers een plek in tentoonstellingen. Daarbij kan het gaan om getuigenissen uit de tijd zelf, van zeventiende-eeuwse rechtbankverslagen of brieven tot oral history interviews over het recente verleden. In 2013 werden banieren, gemaakt van stof uit Suriname, aan de tentoonstelling De Gouden Eeuw toegevoegd. Amsterdammers van nu, nazaten van slaafgemaakten, waren uitgenodigd te reageren op de objecten in de tentoonstelling. Tussen schilderijen van de grachtengordel hing bijvoorbeeld een citaat van wintipriesteres Marian Markelo: 'Als ik langs de grachten loop, zeg ik wel eens: ik ben ook een beetje eigenaar van dit pand, want mijn voorouders hebben er hard voor gewerkt. Onbetaalde arbeid' (zie afbeelding 1).

In een zaal over de West-Indische Compagnie in het Amsterdam Museum hing een uitspraak van historicus Leo Balai over de gewetenloze bewindhebbers. In de laatste zaal, waarin teruggekeken werd op de Gouden Eeuw, hing de uitspraak van Gilbert Wawoe, voorzitter van het comité van aanbeveling voor het slavernijmonument: 'Je kunt niet zielig in een hoekje gaan zitten en zeggen: ik ben zielig want mijn oma was een slaaf.' Deze uitspraken, gedrukt op kleurrijke stof van het Kotomuseum in Paramaribo, plaatsten de objecten uit de zeventiende en achttiende eeuw in een ander perspectief.

Het herdenkingsjaar 2013, 150 jaar na de formele afschaffing van de slavernij in Suriname en op de voormalig Antillen, was ook belangrijk omdat er nieuwe connecties ontstonden. Bijvoorbeeld met de 'Black Heritage Amsterdam Tours' en het 
'Mapping Slavery'-project, die leidden tot de Gids Slavernijverleden Amsterdam (Hondius e.a., 2018). Het Amsterdam Museum werkt daarnaast sinds 2014 samen met grassroot organisatie Stichting Eer en Herstel, die jaarlijks de Memre Waka organiseert. Deze herdenkingstocht, die het begin markeert van de slavernijherdenkingsmaand juni, vertrekt vanaf de binnenplaats van het Amsterdam Museum. Met Mercedes Zandwijken, een activiste die de Keti Koti-dialoogtafels heeft opgericht waar gesprekken gevoerd worden over racisme en andere hedendaagse erfenissen van het slavernijverleden, organiseerden we in 2013 een maaltijd in het Amsterdam Museum.

Bij de tentoonstelling Zwart Amsterdam in 2016 gingen gastconservator Imara Limon en medewerkers van het Amsterdam Museum op pad om tijdens het Keti Koti-festival, de herdenking van de afschaffing van de slavernij, en een talkshow op het jaarlijkse Kwaku-zomerfestival in Zuidoost aan (zwarte) Amsterdammers te vragen wie hun rolmodellen zijn en wie daarvan een plek zou moeten krijgen in het museum. Dat werden beroemdheden als Sylvana Simons, Anton de Kom en Humberto Tan, maar ook een moeder die alleen haar kinderen opvoedde en een voetbalcoach. Imara Limon, inmiddels in de rol van conservator van het Amsterdam Museum, nam ook het initiatief tot de 'New Narrative'-tours, waar mensen van buiten hun commentaar kunnen leveren op het museum. Dat kan pijnlijk zijn, zoals de kritiek die Simone Zeefuik in 2016 uitte op de de-humaniserende manier van het verbeelden van een tot slaaf gemaakte op een infographicwand in de 'Gouden Eeuw'-zaal. Deze kritiek leidde tot een interne discussie over de noodzaak van het veranderen van een gedeelte van de bestaande opstelling. Na hernieuwde kritiek verdween het gewraakte beeld in 2018.

Recentelijk, in december 2018, analyseerden en deconstrueerden achttien jonge museumprofessionals uit landen waar Nederland een 'gedeelde geschiedenis' mee heeft een aantal zalen van het Amsterdam Museum (De Wildt, 2018). Het was een leerzame ervaring om het verhaal van de stad vanuit de perspectieven te bekijken van mensen uit de gebieden die door Amsterdam geëxploiteerd zijn. Hun inzichten zullen zeker een rol spelen bij het nadenken over veranderingen in de huidige en toekomstige tentoonstellingen in het Amsterdam Museum.

Gesprekken over de beladenheid van taal en het bewustzijn van het eigen perspectief als museummedewerker hebben in het Tropenmuseum geleid tot de publicatie WORDS MATTER (Lelijveld \& Modest, 2019). Het boek is een aanmoediging voor organisaties in de culturele sector, musea specifiek, om gesprekken te voeren over het omgaan met taal. WORDS MATTER biedt inzicht en alternatieven. We hopen dat mensen hier actief mee aan de slag gaan, met anderen in gesprek gaan en aanvullingen voorstellen. Door dit te doen bewegen ze zich in debatten die ook buiten de culturele sector gevoerd worden, zoals de gesprekken over beladen straatnamen. Dit kan helpen om beter te begrijpen wat beledigend is voor de en, maar niet zo ervaren wordt door een ander. Het kritisch nadenken over de beschrijving van een object is daarom net zo belangrijk als het object zelf. 


\section{Collectie}

Dekolonisatie van het museum kan ook een andere omgang met de collectie betekenen. Het Amsterdam Museum heeft veel geleerd van de omgang met het Kabramasker. Dit masker is gemaakt door kunstenaar Boris van Berkum in samenspraak met wintipriesteres Marian Markelo. Winti is een religie die zich ontwikkelde op de Surinaamse plantages, meestal in het verborgene, vanuit de oorspronkelijke Afrikaanse religies en inheems Zuid-Amerikaanse invloeden. Marian Markelo streeft ernaar in winti het gebruik van beelden terug te brengen, dat verloren is gegaan door de 'Middle Passage', de ontvoering van Afrikanen op slavenschepen. Kabra refereert aan de voorouders. Het Kabra-masker is, via een 3D-scan, gemaakt op basis van een vooroudermasker van de Yoruba-gemeenschap uit Nigeria, uit de collectie van het Nationaal Museum van Wereldculturen. De 3D-print is groter dan het originele masker en voorzien van een kostuum, zodat er mee gedanst kan worden. Het Amsterdam Museum heeft dit unieke object opgenomen in de collectie, met de bepaling dat het door de Surinaamse gemeenschap geleend kan worden om op te treden tijdens het Keti Koti-festival in het Oosterpark (zie afbeelding 2). De gemeenschappelijke verantwoordelijkheid voor dit object leidt tot nieuwe connecties, inzichten en veranderingen van museale praktijken. Het masker beweegt zich tussen erfgoed, religie en kunst, omdat de religieuze functie van dit museumobject jaarlijks op het festival tot leven komt. Volgens antropoloog Marcus Balkenhol is het masker daarom belangrijk in debatten over 'belonging, citizenship and cultural heritage' (Balkenhol, 2018). Winti is, vanwege de bestrijding ervan door christelijke groepen in de koloniale tijd en het verbod op winti van de Nederlandse overheersers, nog steeds een taboeonderwerp voor sommige Surinamers. Het Kabra-masker maakt het spreken over winti en het belang van de voorouders makkelijker binnen de Surinaamse gemeenschap. Helemaal onomstreden is het masker niet: de Surinaamse gemeenschap discussieert over de afkomst, achtergrond en (witte) huidskleur van de kunstenaar.

\section{White privilege}

In zijn bijdrage aan de publicatie $C O-L A B$, met reflecties over de tentoonstelling Het heden van het slavernijverleden, vraagt medeoprichter van The Black Archives Mitchell Esajas zich af of een voormalig koloniaal instituut als het Tropenmuseum ooit werkelijk gedekoloniseerd kan worden (Esajas, 2019). Wij beseffen ons terdege dat er voor deze dekolonisatie meer nodig is dan het veranderen van woorden of het aandacht schenken aan slavernij. De dekolonisatie van museum gaat ook om staffuncties, om marketing en om kritisch nadenken over de herkomst van de collectie. Voor musea betekent dit transcultureel denken: geen norm van witte, mannelijke, hetero en cisgender single stories, maar verhalen vanuit meerdere perspectieven.

Wie mag het verhaal vertellen van een groep of een gemeenschap? Die vraag speelt al decennia in debatten in historische en stadsmusea. Het Amsterdam 


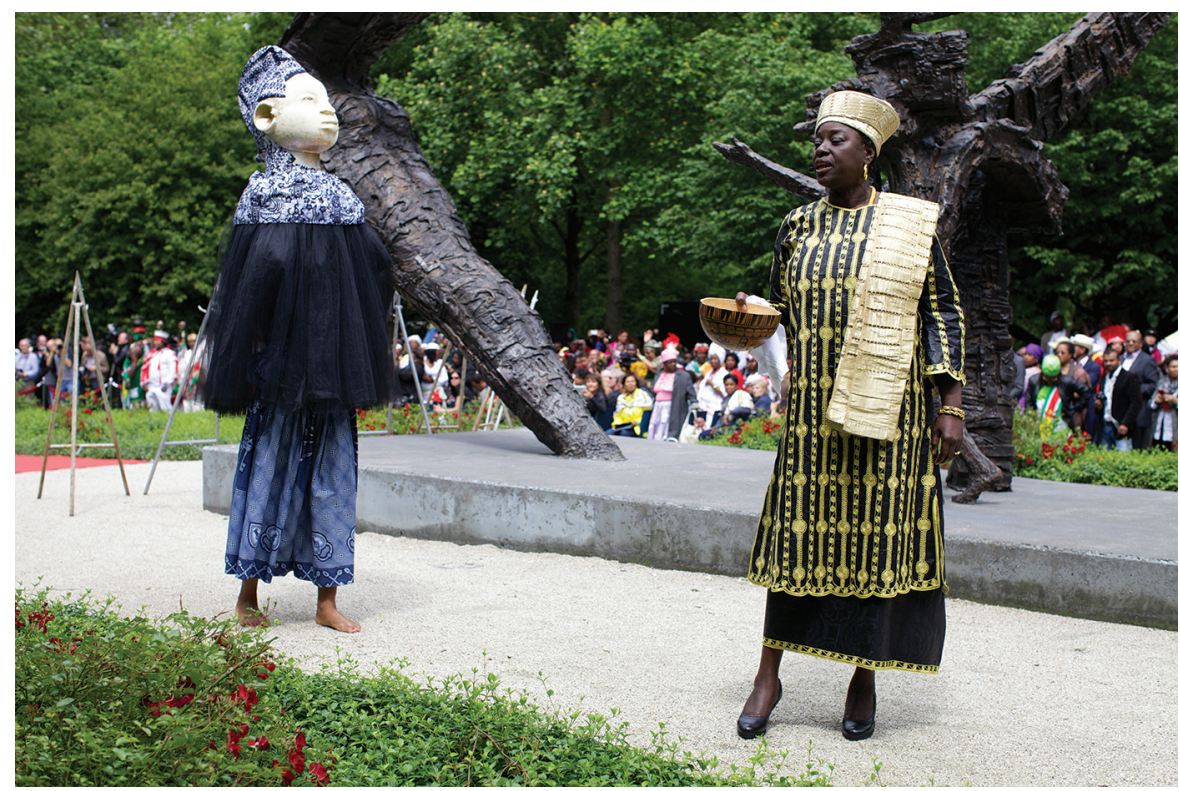

Figuur 2 Marian Markelo, ook bekend als Nana Efua, en het Kabra-masker tijdens de Keti Koti-herdenking op 1 juli 2013.

Museum wijdde tentoonstellingen aan onder anderen prostituees, buurtwinkeliers, islamitische hoofddoekendraagsters, voetbalfans, graffitischrijvers en transgenders. Dit gebeurde altijd in samenspraak met individuen en organisaties die deze groepen representeren. Kwesties rondom het omgaan met persoonlijke verhalen en objecten en sharing authority speelden hierbij altijd een rol (De Wildt, 2018). Bij de discussie over slavernij spelen ook schuld en schaamte een rol. Soms stuit het Amsterdam Museum op (begrijpelijk) wantrouwen als 'wit instituut'. Het is belangrijk dat een stadsmuseum onomwonden laat zien dat de stad in het verleden een belangrijke rol gespeeld heeft bij slavernij en slavenhandel. Het is gedeelde geschiedenis, zoals bij het slavernijmonument in het Oosterpark geschreven staat, en niet alleen de geschiedenis van de mensen wiens voorouders in slavernij leefden.

Dat betekent dat ook bezoekers, in het Amsterdam Museum overwegend wit en hoogopgeleid, op een andere manier naar zichzelf moeten leren kijken. Voor de tentoonstelling Zwart Amsterdam, tijdens de eerste Black Achievement Month in 2016, inspireerde het boek Americanah van Chimamanda Ngozi Adichie tot het creëren van een 'white privilege'-test voor bezoekers. In het boek schrijft de hoofdpersoon namelijk een blog over een 'white privilege'-test, geïnspireerd op het artikel 'White Privilege' van de Amerikaanse feministe Peggy McIntosh uit 1988, waarin zij de voordelen van een witte huidskleur onderzoekt (De Wildt, 2016). Het invullen van de test en de vergelijking met anderen was een effectieve manier om bezoekers zich te laten realiseren dat een verschil in huidskleur tot verschillende ervaringen leidt (zie afbeelding 3). 


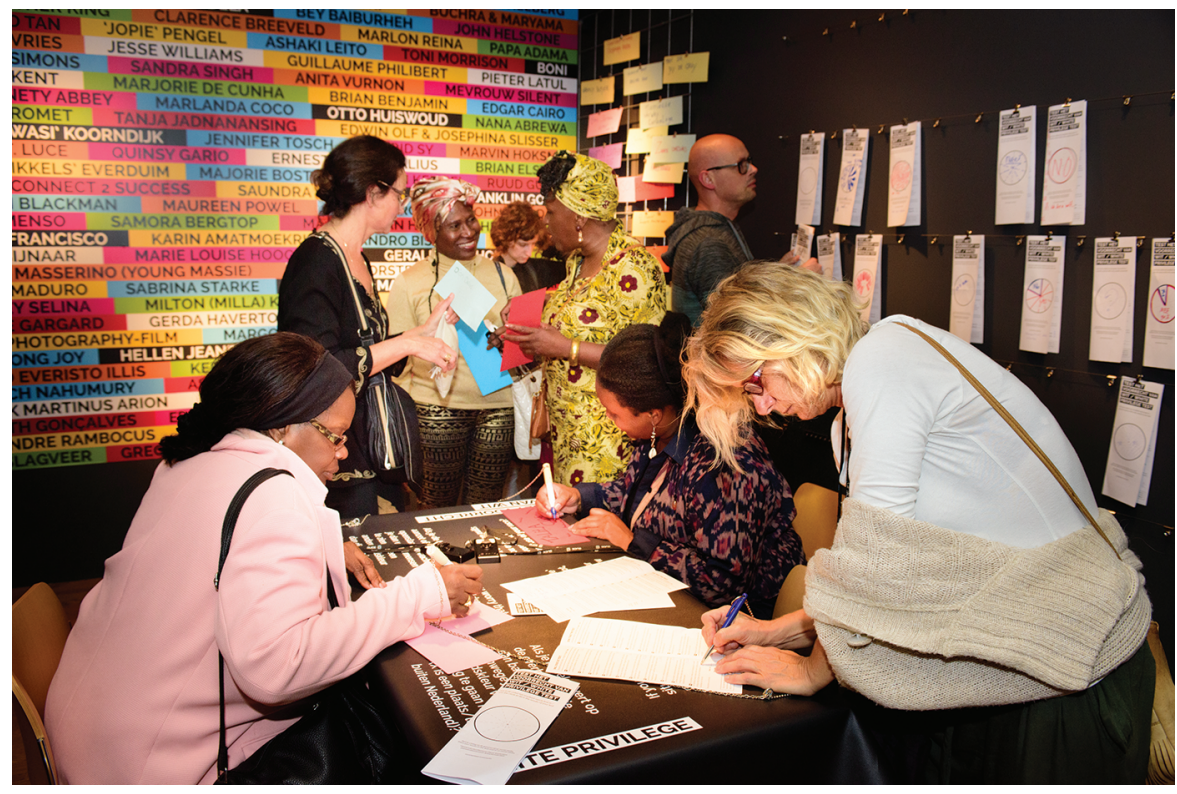

Figuur $3 \quad$ Invullen van de 'white privilege'-test tijdens de opening van Zwart Amsterdam, oktober 2016. Foto Amsterdam Museum, Monique Vermeulen.

Als museummakers moeten wij onszelf dezelfde spiegel voorhouden. Wie zijn wij om met de gedeelde geschiedenis en het beladen erfgoed aan het werk te gaan? Het eerste programma dat Richard Kofi bij het Afrika Museum samenstelde, was een hiphopprogrammering voor de jaarlijkse viering van het Keti Koti-festival in het museum. Samen met Marcellino van Callias en Georgios Lazakis kwam een programma tot stand waarin twee groepen talentvolle creatieve jongeren met verschillende achtergronden een voorstelling gaven over hun band met het slavernijverleden. De groep was heel divers. Richard identificeert zich als Zwart, maar kreeg van sommige bezoekers via via de vraag waarom het Afrika Museum als wit instituut besloten had op 'hun' viering een programma te maken met jongeren waarvan sommigen geen link met het trans-Atlantische slavernijverleden hadden. Voor Zwarte tentoonstellingsmakers als Kofi speelt vaker de vraag hoe ze zich moeten manifesteren binnen de contouren van een wit instituut. Bovendien heeft hij als Ghanese Nederlander een andere verhouding tot het slavernijverleden dan Surinaamse-Nederlanders.

Eén podium dekoloniseert het instituut niet; één niet-wit, niet-cisgender of feministisch perspectief alleen is niet genoeg. De dekolonisatie van onze instituten is niet te bereiken door middel van een gezellige samenwerking met leuke partners waarmee de museummaker met fijne promotieacties zomaar even een nieuwe doelgroep bereikt. Het is een veel intensiever proces, waarbij het nog maar de vraag is of het ooit werkelijk af is. Het vereist een andere manier van denken, waarin geprobeerd wordt te breken met een verleden met voelbare consequenties 
voor de traditie van het museum. De dekolonisatie is het herstellen van een incorrecte beeldvorming en een onterecht eenzijdige witte, cisgender-, heteroblik op kunst en erfgoed. Het is inspirerend en vaak heel leuk om onderdeel te zijn van een dergelijke verbetering, maar het herstellen van een disbalans kun je eigenlijk niet 'vieren'.

\section{'We zijn er' - zijn we er?}

Zijn musea de beste plekken om het slavernijverleden onder de aandacht te brengen? In maart 2016 werd in een uitverkocht Paradiso voor een overwegend jong en zwart publiek het boek Roofstaat gepresenteerd, uitgegeven door hiphoplabel TopNotch. Er waren optredens en er werd een quiz gehouden over Nederland en slavernij. De indrukwekkende clip van Typhoon, We zijn er, ging in première, die toont hoe de zanger tot slaaf wordt gemaakt en gegeseld, waarna hij de zweep pakt die tot een microfoon transformeert. Het nummer is ontstaan vanuit boosheid. De clip dreigde aanvankelijk een subsidie van het TAX-videoclipfonds mis te lopen omdat het onderwerp te 'precair' zou zijn, maar kreeg die uiteindelijk wel (Kloet, 2016). Hiphop, videoclips en spoken word zijn waarschijnlijk betere manieren om verhalen over slavernij te delen dan achttiende-eeuwse schilderijen. In een museumzaal over de Gouden Eeuw zou Tyfoons We zijn er een kantelmoment kunnen forceren om het gesprek over slavernij te beginnen.

Het gezegde gaat dat 'een beeld meer zegt dan duizend woorden', maar uit de reacties op Het heden van het slavernijverleden in het Tropenmuseum blijkt dat poëzie en spoken word meer kunnen zeggen dan duizend beelden. De tentoonstelling heeft twee ingangen en aan beide kanten worden de bezoekers welkom geheten met poëzie. Dichters Dorothy Blokland en Onias Landveld vertellen in twee video's over hun eigen verhouding tot het slavernijverleden. Onias vertelt hoe de talen, de woorden en de geschiedenissen van zijn voorouders in hem met elkaar verbonden zijn. Dorothy nodigt de bezoekers uit mee te gaan in haar zoektocht naar de betekenis van vrijheid. Ze gaat op zoek in haar 'black archives'. Het Tropenmuseum krijgt op beide video's ontzettend veel reacties, zelfs van bezoekers die thema's als racisme en slavernij maar overdreven vinden. Zij vonden bijvoorbeeld de tentoonstelling niet goed, maar konden wel begrip opbrengen voor Onias en Dorothy. Andere bezoekers interpreteerden Dorothy's theatraliteit als boosheid, terwijl haar handreiking en woorden juist heel lief zijn. Deze verschillende manieren van kijken maken de complexiteit van onze onderlinge relaties voelbaar.

\section{Conclusies}

'Praten over één zwarte bladzijde? Er zit niet eens een witte tussen', zei auteur Ewald Vanvugt bij de presentatie van Roofstaat en hij kreeg een ovatie vanuit de zaal. Is dat zo? Een kunstenaar als Typhoon kan zijn eigen perspectief tonen. Het museum zou bij uitstek de plek moeten zijn waar getoond wordt dat onze geschiedenis morele en amorele gebeurtenissen en daden bevat en dat deze combinatie 
het heden en onze hedendaagse verhoudingen bepaald. Moraal, normen en waarden veranderen voortdurend. De erkenning van de impact van het slavernijverleden op het heden alleen is niet genoeg, ook al is zelfs dat soms nogal moeizaam. Het gaat om het toelaten van de perspectieven die zich buiten de kaders van het dominante narratief bevinden. Karwan Fatah-Black komt tot een belangwekkende conclusie: we moeten onszelf en anderen met nog meer inzet leren hoe we de ontwikkeling van nieuwe perspectieven kunnen verbinden aan het zoeken naar feiten in de archieven (Fatah-Black, 2019). Persoonlijke verhalen van slaafgemaakten leveren andere kennis/feiten op dan de administratie van een plantage. Daarnaast is ook onderzoek naar de werking van het 'cultureel archief' essentieel (Wekker, 2017).

In onze museale praktijk is een wisselwerking tussen onderzoekers, activisten, kunstenaars en museummedewerkers belangrijk. Er is niet één recept voor de dekolonisatie van een museum, maar het is zinvol om door middel van samenwerkingen met groepen van buiten het museum vanuit verschillende perspectieven te bedenken/onderzoeken hoe het slavernijverleden en de gevolgen daarvan zichtbaar gemaakt kunnen worden. Het is belangrijk om daarbij de emoties die het onderwerp oproept niet uit de weg te gaan. Het is namelijk een urgente kwestie: om Nederland als een diverse (multiculturele) samenleving te laten slagen moet de grauwe kant van het koloniale verleden benoemd, begrepen en erkend worden.

\section{Literatuur}

Balkenhol, M. (2018). Iconic objects. Making blackness, whiteness, and diasporic heritage in the Netherlands. In: B. Meyer \& M. van de Port (red.), Sense and Essence. Heritage and the Cultural Production of the Real. New York: Berghahn Books.

Esajas, M. (2019). Can the former colonial museum truly be decolonized?. In: R. Lelijveld \& N. Rijnks-Kleikamp (red.), CO-LAB, Afterlives of slavery. Leiden: RCMC, 31-32. https:// issuu.com/tropenmuseum/docs/zine_colab_def_onlineversie/3?ff\&e=1823887/ 66204021. Geraadpleegd op 14 maart 2019.

Fatah-Black, K. (2019). We need praxis to rewrite history. In: R. Lelijveld \& N. Rijnks-Kleikamp (red.), CO-LAB, Afterlives of slavery. Leiden: RCMC, 34-35. https://issuu.com/ tropenmuseum/docs/zine_colab_def_onlineversie. Geraadpleegd op 14 maart 2019.

Hondius, D., Jouwe, N., Tosh, J., Stam, D., \& Wildt. A. de (2018). Gids Slavernijverleden Amsterdam. Amsterdam: LM Publishers.

Jouwe, N. (2018). Sites for Unlearning in the Museum. In: B. Choi, A. Krauss \& Y. van der Heide (red.), Unlearning Exercises. Art Organizations as Sites for Unlearning. Amsterdam/Utrecht: Valiz/Casco Art Institute, 129-143.

Kloet, F. (2016). Typhoon kruipt in de huid van een slaaf: 'Laten we nu het gesprek aangaan', 3 voor 12, 15 maart. https://3voor12.vpro.nl/artikelen/overzicht/2016/Maart/ Cliprelease-presentatie-Roofstaat . Geraadpleegd op 14 maart 2019.

Lelijveld, R., \& Modest, W. (2018). WORDS MATTER, An Unfinished Guide to Word Choices in the Cultural Sector. Leiden: National Museum of World Cultures. https://www. tropenmuseum.nl/sites/default/files/2018-06/WordsMatter_Nederlands.PDF. Geraadpleegd op 14 maart 2019. 
Lelijveld, R., \& Rijnks-Kleikamp, N. (red.) (2019). CO-LAB, Afterlives of slavery. Leiden: RCMC. https://issuu.com/tropenmuseum/docs/zine_colab_def_onlineversie/3?ff\&e= 1823887/66204021. Geraadpleegd op 14 maart 2019.

Neslo, E. (2016). Een ongekende elite: De opkomst van een gekleurde elite in Koloniaal Suriname 1800-1863. De Bilt: Haes Producties.

Reichwein, G. (2016). Out of history. Een drieluik van Iris Kensmil. hart.amsterdam, 9 maart. www.hart.amsterdam/nl/page/54341/out-of-history. Geraadpleegd op 14 maart 2019.

Stipriaan, A. van (2009). De kunst van overleven. Marroncultuur uit Suriname. Amsterdam: LM Publishers.

Wekker, G. (2017). Witte onschuld. Paradoxen van kolonialisme en ras. Amsterdam: AUP.

Wildt, A. de (2016). White privilege. Test het Voorrecht van Wit. hart.amsterdam, 19 november. https://hart.amsterdam/nl/page/101220. Geraadpleegd op 14 maart 2019.

Wildt, A. de (2018). The city museum as an empathic space, Museums and Contested Histories. Museum International, 70: 3-4, 72-83.

Wildt, A. de (2019). Verhalen delen. Over betwiste geschiedenissen. hart.amsterdam, 25 januari. https://hart.amsterdam/nl/page/689415/verhalen-delen. Geraadpleegd op 14 maart 2019. 